\title{
Museumsutdanning i Norge - eksisterer det?
}

\author{
Merethe Frøyland*
}

Det har lenge vært et ønske i Norge om en grunnutdanning og et samordnet etterutdanningstilbud innen museumsområdet, slik biblioteksektoren har. Både den offentlige utredningen (NOU) fra 1996, Museum - mangfold, minne, møteplass og de følgende Stortingsmeldingene som omhandler museumsfeltet, etterlyser slik utdanning.

Behovet for museumsfaglig kompetanse har ikke blitt mindre etter at Museumsreformen ble satt i gang i 2002. Museumsreformen er en statlig storsatsning på museumsfeltet som har bidratt til at museumslandskapet i Norge har endret seg betydelig disse årene, fra over 250 museer med indirekte statlig driftstilskudd, til ca. 100 museer med direkte statlig driftstilskudd i 2006 over Kultur- og kirkedepartementets (KKD) budsjett. Målet med reformen er å etablere sterkere fagmiljøer som vil styrke museene som aktive og aktuelle arenaer for kunnskap og opplevelse. Det betyr at museene har behov for ansatte med en museumsfaglig kompetanse som gjør dette mulig. På grunn av reformen har behovet for museumsfaglig utdanning blitt enda sterkere.

\section{EN OVERSIKT OVER TILbUdET I NORGE}

Nedenfor følger en oppsummering av tilbud innen museumskunnskap, museumsformidling eller museologi gitt innenfor universitetsog høyskolesektoren (UH-sektoren). Annen museumsrelevant utdanning som konservering, er holdt utenfor denne oppsummeringen. Dette er ikke ment å være en fullstendig liste. Det finnes flere mindre kurs/studier som ikke er tatt med. I tillegge finnes det enkeltpersoner som gjennom master- og doktorgradstudiet innenfor andre fagfelt, har valgt å ta utgangspunkt $\mathrm{i}$ museene. Disse er heller ikke tatt med i denne oversikten.

\section{Utdanning i Museumsformidling ved Høgskolen i Oslo \\ (60 studiepoeng)}

Dette er et videreutdanningstilbud med tittelen Museumsformidling som tilbys av Avdeling for journalistikk, bibliotek- og informasjonsfag ved Høgskolen i Oslo. Studiet er på 60 studiepoeng og er først og fremst for ansatte på museer, men andre som er interessert i formidling gjennom kulturinstitusjoner kan også søke.

Studiet er utviklet ved Avdeling for journalistikk, bibliotek- og informasjonsfag ved Høgskolen i Oslo, i samarbeid med Statens senter for arkiv, bibliotek og museumsutvikling (ABM-utvikling), Avdeling for estetiske fag og Avdeling for lærerutdanning. Det første kullet startet høsten 2003 og avsluttet sin utdanning våren 2006. Høgskolen har planer om å videreutvikle studiet til et mastertilbud innen museumsformidling.

Museenes fire hovedoppgaver er dokumentasjon, bevaring, forskning og formidling. I 
88 dette studiet legges hovedvekten på formidling. Studiet skal belyse museenes rolle som kultur- og kunnskapsformidlere og vise hvordan museene kan bidra til å sette viktige samfunnsspørsmål på dagsorden. Formidlerens oppgave er å engasjere et bredt og sammensatt publikum. Studentene vil derfor analysere museenes mål og målgrupper og vurdere bruk av forskjellige formidlingsmetoder kjent fra så vel tradisjonell folkeopplysning som fra mer underholdningspregede, kommersielle tiltak.

Studiet vil spesielt belyse den utfordrende rollen formidleren har. Etiske spørsmål vil stå sentralt. Det vil også være av betydning å studere og drøfte hvordan formidlingsarbeidet drives ved forskjellige museer. I den sammenhengen studeres bl.a. hvordan dette kommer til uttrykk i museenes strategiplaner og i det daglige arbeid ved institusjonene. Studiet vil gi innblikk i de mulighetene som ligger i forskjellige former for formidling, men også belyse de fysiske og økonomiske rammebetingelsene som formidleren må forholde seg til. Det finnes mange små museer, samlinger og kulturinstitusjoner som har hatt meget begrensede muligheter til å arbeide systematisk med formidling og utadrettet virksomhet. Intensjonen er å gi deltakende studenter anledning til å bygge et nettverk som kan bidra til å styrke disse mulighetene også ut over studietiden.

Fagets kunnskapsbase hentes fra teori om læring, didaktikk, formidling og markedsføring. Det legges vekt på basiskunnskaper om blant annet kultur-og utdanningspolitikk og kultur- og vitenskapshistorie. Dette skal gi grunnlag for praktisk formidlingsarbeid som formgivning av utstillinger, muntlige presentasjoner og bruk av digitale formidlingsformer.

Gjennom studiet skal studenten tilegne seg kunnskaper om og kvalifikasjoner innrettet mot å planlegge, tilrettelegge og gjennomføre formidlingsoppgaver til ulike målgrupper i ulike typer museer med vekt på samlingenes egenart og aktuelle utfordringer.

Studiet består av 4 moduler og går over to år. Studiet er organisert i tre samlinger for hvert semester, for å gjøre det mulig å kombinere med jobb.

Studiet er organisert i fire moduler på 15 studiepoeng hver: Museum og samfunn, Utstillinger - utvikling og utforming, Målgrupper og Museumsformidleren.

- Museum og samfunn omfatter museenes virksomhet, visjoner, mål og strategier sett i et historisk og samfunnsmessig perspektiv.

- Utstillinger - utvikling og utforming omfatter planlegging av utstilling, bruk av ulike virkemidler i utstilling, samt enkel farge- og formlære.

- Målgrupper dreier seg om å involvere publikum, med spesiell vekt på barn og unge. Det dreier seg også om hva vi kan forvente av de ulike aldersgruppene og av andre grupper som innvandrere/minoriteter, samt målgrupper med spesielle behov. Emnet omfatter også læreplaner/rammeplaner, fra grunnskolen til den videregående skolen, samt publikumsundersøkelser.

- Museumsformidleren omfatter læringsteorier, praksisteori, formidlerrollen, ulike typer undervisningsopplegg, samt formidleren i dagens praksis.

Studiet kvalifiserer til formidlingsarbeid i ulike typer museer, fra naturvitenskapelige, etnografiske og historiske museer til kunstmuseer, samlinger av forskjellige slag, kulturinstitusjoner, gallerier og lignende.

Mål

Ved avsluttet utdanning skal studenten 
- ha tilegnet seg økt innsikt i og forståelse for de mulighetene som museene representerer for formidling av kunnskap

- ha tilegnet seg kunnskap om museenes rolle både i historisk og samfunnsmessig perspektiv

- ha tilegnet seg kunnskap om og ferdigheter i sentrale pedagogiske teorier og metoder I museumsformidling

- kunne innrette formidlingsmetodene etter ulike målgruppers behov

- kunne reflektere kritisk over de muligheter som ligger i museenes utadrettede virksomhet og bidra til å utnytte disse mulighetene best mulig

- ha tilegnet seg kunnskap om forskjellige former for evaluering av museenes formidlingsarbeid og virkemidler for oppfølging av disse

- ha fătt erfaring med bruk av forskjellige virkemidler i forbindelse med utforming av utstillinger

- kunne gjennomføre formidlingsoppgaver

- vise en yrkesetisk holdning preget av respekt for de grupper og enkeltpersoner som besøker museet

- ha tilegnet seg kunnskap om teamarbeid og kunne bidra til samarbeid mellom ulike profesjoner innen museets arbeidsfelt

Studiet ble første gang tilbudt i 2004 og fikk Høgskolens pris for læringsmiljøet i 2007.

Les mer om studiet:

http://www.hio.no/enheter/avdeling_for_jour nalistikk_bibliotek_og_informasjonsfag/for_s tudenter_jbi/museumsformidling

\section{ABM-utdanning ved Høgskolen i Vestfold - videreutdanning}

30 studiepoeng

Studiet er en etterutdanning med tittelen For- midlingskunnskap for ABM-feltet (Arkiv, Bib-

liotek, Museum) og er på 30 studiepoeng. Målgruppa for studiet er ansatte i ABM-sektoren og har en studieavgift.

Kurset vil omfatte emner som bidrar til å belyse ABM-sektorene og deres samarbeid med utgangspunkt i faglig kunnskap, og vil utvikle evnen til å formidle, særlig innen historie. Innhold/emner i studiet er:

- Arkiv-kunnskap

- Bibliotek-kunnskap

- Museums-kunnskap

- Skoleverkets behov overfor ABM-feltet

- Bruk av historiske kilder

- Historiefortelling

- Formidling av de vanskelige historiene

- Rollen som samfunnsaktør

Målet med studiet er at studentene skal

- kunne tilrettelegge for aktiv formidling i sin ABM-sektor, særlig overfor skoleverket

- ha kunnskap om hele ABM-feltet

- kunne igangsette samarbeid på tvers av sektorene

- ha kjennskap til ulike måter å formidle historie på

Studiet blir første gang tilbudt høsten 2007.

Les mer om studiet: http://www-lu.hive.no/ samfunnsfag/ABM

\section{Museologisk utdanning ved Universitet i \\ Oslo}

20 studiepoeng

Studiets tittel er Museumskunnskap og tilbys ved Institutt for kulturstudier og orientalske språk (IKOS) ved Universitetet i Oslo (UiO).

Det foreligger planer om mastergrad i museologi, men tidspunkt er foreløpig ikke avklart.

Museumskunnskap er et tverrfaglig kultur- 
90 studium. Emnet er et møtested for bl.a. fagene arkeologi, kulturhistorie, kunsthistorie og kunstkonservering. Studiet belyser museumsog samlingshistorie, museumsfilosofi og museumspolitikk.

Museumskunnskap vil i kombinasjon med museumsrelevante fag være egnet som teoretisk bakgrunn for ulike museumstilknyttede oppgaver. I tillegg vil det kunne ha en allmenn nytteverdi gjennom trening i kritisk tenkning og analytisk tilnærming til et kunnskapsfelt. Gjennom studiet skal studentene reflektere over museenes plass i det kulturpolitiske bildet globalt, nasjonalt og lokalt. Studentene skal gjennom studiet skaffe seg innsikt i ulike museers opphavshistorie, innsamlings- og utstillingsproblematikk og museer som kilde til kunnskap og kulturformidling. Museumsfilosofiske og museumspolitiske spørsmål vil også stå sentralt i studiet.

Studiet har vært gjennom en rekker endringer, men har vært et tilbud siden begynnelsen av 1990-tallet.

Les mer om studiet: http://www.uio.no/studier/emner/hf/ikos/MUSKUN2000/

\section{Museologi ved Universitetet i Bergen \\ 15 studiepoeng}

Dette er et kurs med tittel KUVI203 / Museologi som tilbys ved Historisk- filosofisk fakultet ved Universitet i Bergen og er på 15 studiepoeng.

Målgruppa er studenter ved $\mathrm{UiB}$ som har basiskunnskaper innen kulturvitenskap.

Modulen skal gi forutsetninger for å forstå museenes funksjon og virksomhet og den rollen de spiller i samfunnet. Museologi er et fordypningsemne som tematiserer museenes betydning og rolle i samfunnet som et felt for produksjon av forestillinger om fortid og sam- funnet. Det blir vektlagt følgende tema:

1. Begrepet museologi (museet sin rolle i samfunnet, budskap og virksomhet)

2. Museumstyper og museumshistorie

3. Musealisering (materiell kultur, transformering av vanlige ting til kulturarv, hvilke gjenstander kommer på museum, og hva gjør dem meiningsfulle som museumsgjenstander).

4. Formidling (Utstillingsprinsipp - hvilke grep ved utstillinger får fram bestemte budskap? Utstillingsstrategier og utstillingsspråk. Nye formidlingsformer)

5. Aktuelle utfordringer: Museet sin kulturelle betydning i dag.

Les mer om studiet:

http://studere.uib.no/?link_id=405\&sublink_id=\&toplink_id $=\&$ mode $=$ show_page $\& \mathrm{c}$ ontent_id=525\&\&modus=vis_emne $\&$ kode $=$ KUVI203

\section{Museologi ved Norges Teknisk-Naturviten- skapelige Universitet (NTNU)}

15 studiepoeng

Studiet har tittelen Kulturminneforvaltning og museologi er knyttet til Arkeologi.

Målet med kurset er å gi fordypet innsikt i forvaltningsteori- og praksis og museumskunnskap med særlig vekt på formidling.

Kurset er delt inn i to moduler. Modul I omhandler kulturminneforvaltning og retter seg mot forvaltningsteori i form av vernefilosofi, byråkratisering og kulturminnefeltet som politikkområde, noe som innebærer forvaltningshistorikk og forvaltningssystemets oppbygging. Modulen omfatter også gjennomgang av relevante lovverk og prosesser som konsekvensutredning, planprosess, dispensasjon og skjøtsel. Videre berøres også forhold som prosjektutforming og registerproblematikk. 
Modul II, med tema Museologi retter seg primært mot ulike sider ved formidling av fortidskunnskap. Hovedtema er ulike formidlingsmåter som utstillingsvirksomhet, populærvitenskapelige publikasjoner og foredrag, omvisninger, formidling i feltsituasjon og mediahåndtering. Modulen omhandler også forhold som motiver bak, behovet for og effekten av formidling.

Les mer:

http://www.hf.ntnu.no/hf/adm/studier/studiehandboka/bok/s20072008/studieplaner/forord_historie_kultur/arkeologi/vis_emne?emnekode=ARK3314

\section{ENDELIG ET TILBUD?}

De fleste museumsrelevante kurstilbud i Norge blir arrangert av museumsorganisasjoner og institusjoner utenfor UH-sektoren. I tillegg tilbyr Statens senter for arkiv, bibliotek og museumsutvikling (ABM-utvikling) stipend til de som ønsker å ta en museumsrelevant utdanning i utlandet. Flere har benyttet dette tilbudet og tatt en utdanning blant annet i Sverige eller England.

Tilbudet innenfor UH-sektoren, er som oversikten over viser, nær knyttet til et utdanningsforløp innenfor historiefag og/eller arkeologi. Det er først i 2004 med studiet i $M u$ seumsformidling ved Høgskolen i Oslo, at vi făr et større utdanningstilbud på tvers av faggrenser. Men ingen av disse tilbudene er å betrakte som et fullverdig utdanningstilbud, og det dekker på langt nær det behovet museene har i dag for kompetanse.

Foreløpig foreligger det to planer for masterstudier innen museumsutdanning. Den ene planen er å utvide Museumsformidlings-studiet ved Høgskolen i Oslo til et masterstudiet, og den andre planene er å bygge videre på Museumskunnskap ved Universitetet i Oslo til et masterstudiet i museologi. Dersom disse planene blir en realitet vil vi endelig kunne si at Norge også har museumsutdanning. Dette vil være viktige bidrag til den museumsfaglige kompetansen de norske museene har behov for.

*Førsteamanuensis Merethe Frøyland

Address: Naturfagsenteret

Postboks 1099, Blindern, 0317 Oslo

Fax: 22854409

Tlf: 22855337

E-post:post@naturfagsenteret.no

Direkte e-post er fremdeles:

merethe.froyland@abm-utvikling.no 